\title{
The Comparison of Salivary Ph Changes After Consuming Chicken Banana (Musa Acuminata Colla) Among the First Semester of Diploma Students of Dental Nursing of Poltekkes Kemenkes Tasikmalaya 2019
}

\author{
$1^{\text {st }} S$ Faisal Manalu \\ Department of Dental Nursing \\ Poltekkes Kemenkes Tasikmalaya \\ Tasikmalaya, Indonesia \\ $4^{\text {th }}$ C Rahayu \\ Department of Oral Health Therapy \\ Poltekkes Kemenkes Tasikmalaya \\ Tasikmalaya, Indonesia \\ culiarahayu@yahoo.com
}

\author{
$2^{\text {nd }}$ E Kammelia \\ Department of Oral Health Therapy \\ Poltekkes Kemenkes Tasikmalaya \\ Tasikmalaya, Indonesia \\ $5^{\text {th }}$ T Kartika Dewi \\ Department of Oral Health Therapy \\ Poltekkes Kemenkes Tasikmalaya \\ Tasikmalaya, Indonesia
}

\author{
$3^{\text {rd }} \mathrm{T}$ Ambarwati \\ Department of Oral Health Therapy \\ Poltekkes Kemenkes Tasikmalaya \\ Tasikmalaya, Indonesia \\ $6^{\text {th }} \mathrm{H}$ Miko \\ Department of Oral Health Therapy \\ Poltekkes Kemenkes Tasikmalaya \\ Tasikmalaya, Indonesia
}

\begin{abstract}
The content of fermented carbohydrates in chicken bananas (musa acuminata colla) can cause the oral cavity to become acidic and in a state of the acidic oral cavity can trigger the process of caries. The purpose of this study was to determine the comparison of salivary $\mathrm{pH}$ before and after consuming chicken bananas (musa acuminata colla) in Diploma students of the Dental Nursing Department of Poltekkes Kemenkes Tasikmalaya. This design of the research is a quasi-experimental with a form of nonequivalent control group research or often also called a nonrandomized control group pretest-posttest design. The population of this research was all the first semester of Diploma students of the Department of Dental Nursing Poltekkes Tasikmalaya. Analysis of differences in salivary pH before and after consuming chicken bananas (musa acuminata colla), tested based on the $\mathrm{pH}$ of saliva between before and after consuming chicken bananas (musa acuminata colla) in the experimental group, then compared with the control group that was examined for salivary pH but was not given treatment. Statistical test data used are paired sample t-test. The results of the study of the average value of saliva $\mathrm{pH}$ before consuming the banana chicken (musa acuminata colla) of 7,102 included in the criteria of bases and salivary $\mathrm{pH}$ after consuming the banana chicken (musa acuminata colla) of 6.853 including the acid criteria, the results of the examination were quite significant, whereas $P$-value of the T-test is 0.00 which means the probability is less than 0.05 , The conclusion of this research was there was a significant difference in salivary $\mathrm{pH}$ before and after consuming chicken bananas (musa acuminata colla).
\end{abstract}

Keywords-Salivary Ph, Chicken, Banana (Musa Acuminata Colla)

\section{INTRODUCTION}

Dental and oral health is often the umpteenth priority for most people in Indonesia, almost $90 \%$ of Indonesian people experience a toothache. Basic Health Research 2018 states that the proportion of caries problems in
Indonesia is at a presentation of $45.3 \%$ and especially in West Java at a presentation of $45.7 \%$ [2].

The factor that has an important role in the formation of caries is saliva. Saliva is a liquid secretion in the mouth that is in contact with the mucosa and teeth, which comes from 3 pairs of major salivary glands and minor salivary glands in the oral mucosa [6].

The power of Hydrogen $(\mathrm{pH})$ is a unit of measurement that describes the degree of acidity or alkali content of a solution. The $\mathrm{pH}$ unit is measured on a scale from 0 to 14 [8]. A decrease in salivary $\mathrm{pH}$ can increase the risk of high caries, while an increase in salivary $\mathrm{pH}$ can increase the formation of tartar (calculus). The degree of acidity ( $\mathrm{pH}$ ) of saliva can change and factors that affect changes in salivary $\mathrm{pH}$ are diet, day and night rhythm, and secretion of secretion.[9]. Foods that contain carbohydrates will trigger a decrease in the acidity $(\mathrm{pH})$ of saliva to become acidic and if it reaches a critical $\mathrm{pH}$ point $(\mathrm{pH} \leq 5.5)$ will facilitate the process of demineralization of enamel so that the occurrence of caries [4 10].

Caries is a disease characterized by tissue damage, starting from the surface of the teeth (niches, fissures, and interproximal regions) extending to the pulp area (braver) [12].

Chicken banana (musa acuminata colla) or better known as barangan banana is a typical type of banana Talun Kenas, Deli Serdang, North Sumatra, chicken bananas contain high carbohydrate, which is around $22.84 \mathrm{gr}$, sugar $12.23 \mathrm{gr}$, fiber $2,6 \mathrm{gr}$, in addition, it contains protein, fat, vitamins and much more [5].

The first semester of Diploma students of the Dental Nursing Department of Poltekkes Kemenkes Tasikmalaya is a collection of selected and tested students, around 1719 years old. World Health Organization (WHO) revealed that the group of adolescents is in the age group of 10-20 
years, which is divided into 2, namely early adolescents and aged 10-14 years as early adolescents and late adolescents at the age of 15-20 years [11], in other words, the first semester of Diploma students of the Dental Nursing Department of Poltekkes Kemenkes Tasikmalaya is in the late adolescent group. Late adolescence is a period of adolescent perfection (adolescence proper) and is the culmination of emotional development. This stage is also a period of consolidation towards the early adult period and psychologically at this time individuals will be more organized themselves into later adulthood [11].

Preliminary research conducted by researchers on Saturday 12 January 2019 using the questionnaire filling method through 10 First semester of Diploma students obtained $100 \%$ data of respondents like eating bananas, but only $20 \%$ who often eat bananas, and also only $10 \%$ of respondents who know the chicken banana (musa acuminata colla). The interesting thing that was obtained from the Preliminary research was the reason the respondents liked eating bananas because it was beneficial for body health apart from its good taste, but only $10 \%$ of respondents knew the effect of consuming bananas on oral health.

\section{RESEARCH METHOD}

This design of the research is a quasi-experimental with a form of non-equivalent control group research or often also called a non-randomized control group pretestposttest design. [7] The sample in this research was the first semester of the Dental Nursing Department of Poltekkes Kemenkes Tasikmlaya consisting of 40 people with a sampling used total sampling with inclusion criteria, then the sample population was divided into 2 groups: the control group and the experimental group. The instrument used are chicken bananas in a ripe condition, more yellow to orange with brown spots around the banana peel, besides that the chicken banana has a delicious aroma with soft banana meat. Each sample obtained $100 \mathrm{gr}$ of banana chicken for consumption. The examination of the sample control group was carried out on Monday 11 February 2019 starting from 08.00 to 10:00. The saliva collection method used is the spitting method [1]. Samples are collected in classrooms and sit quietly, then samples are instructed to collect saliva in the oral cavity and then spit into the container that has been provided and then measured using a $\mathrm{pH}$ meter. The sample is determined to wait for 10 minutes then the sample collects saliva as previously done and is measured again using a $\mathrm{pH}$ meter.

The examination of the sample of the experimental group was conducted on Tuesday 12 February 2019 starting at 08.00 to 10.30 . The activities carried out are almost the same as the samples in the control group, the difference lies in the treatment. The sample of the experimental group was instructed to sit quietly then collect saliva in the oral cavity and then spit into the container provided. After measuring the $\mathrm{pH}$ of the saliva, the sample was instructed to consume a $100 \mathrm{~g}$ chicken banana until blended and then swallowed for 1 minute. Then saliva is collected again to be measured using a $p H$ meter.

This data analysis uses paired sample t-test statistical tests and is carried out using the Statistical Package for the Social Science (SPSS) version 16 so that the results of the data processing produce a report that is easy to read and easy to interpret.

\section{RESULT AND DISCUSSION}

Frequency distribution of research samples by sex there were 6 male samples and 34 female samples. Salivary $\mathrm{pH}$ examination results in the control group can be seen in the table 1.

TABLE 1. RESULTS OF SALIVARY PH EXAMINATION IN THE CONTROL GROUP

\begin{tabular}{ccccc}
\hline & & & Sex & \multicolumn{2}{c}{ Salivary $p$ Check in the Control Group } \\
\cline { 3 - 5 } No & Sample & $\begin{array}{c}\text { F(Female) } \\
\text { (Male) }\end{array}$ & Before & After \\
\hline 1 & S-1 & F & 6.90 & 6.92 \\
\hline 2 & S-2 & M & 6.80 & 6.75 \\
\hline 3 & S-3 & F & 6.95 & 6.93 \\
\hline 4 & S-4 & F & 7.05 & 7.07 \\
\hline 5 & S-5 & M & 7.20 & 7.18 \\
\hline 6 & S-6 & F & 6.90 & 6.87 \\
\hline 7 & S-7 & F & 7.00 & 7.03 \\
\hline 8 & S-8 & F & 7.12 & 7.14 \\
\hline 9 & S-9 & F & 7.18 & 7.12 \\
\hline 10 & S-10 & F & 7.10 & 6.67 \\
\hline 11 & S-11 & F & 6.65 & 6.85 \\
\hline 12 & S-12 & F & 6.87 & 6.70 \\
\hline 13 & S-13 & M & 6.72 & 6.78 \\
\hline 14 & S-14 & F & 6.80 & 7.18 \\
\hline 15 & S-15 & F & 7.20 & 7.13 \\
\hline 16 & S-16 & M & 7.15 & 7.21 \\
\hline 17 & S-17 & F & 7.25 & 7.17 \\
\hline 18 & S-18 & & 7.15 & \\
\hline
\end{tabular}




\begin{tabular}{lllll}
\hline 19 & S-19 & F & 6.75 & 6.77 \\
\hline 20 & S-20 & F & 6.92 & 6.92 \\
\hline
\end{tabular}

Graph of changes in salivary $\mathrm{pH}$ results before and after in the control group can be seen as follows

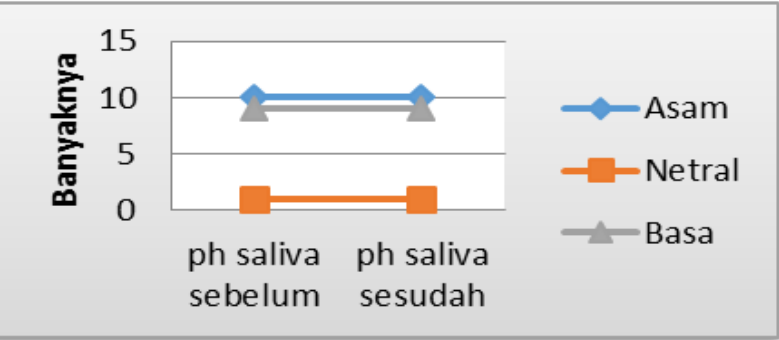

Figure 1. Graph of changes in salivary $\mathrm{pH}$ before and after in the control group

Salivary $p H$ examination results in the control group can be seen in the table 2 .

TABLE 2. RESULTS OF SALIVARY PH EXAMINATION IN THE EXPERIMENTAL GROUP

\begin{tabular}{|c|c|c|c|c|}
\hline \multirow{2}{*}{ No } & Sample & \multirow{2}{*}{$\begin{array}{c}\text { Sex } \\
\text { F(Female) } \mathbf{M} \\
\text { (Male) }\end{array}$} & Sefore & After \\
\cline { 4 - 5 } & & M & 7.30 & 7.00 \\
\hline 1 & S-1 & F & 7.15 & 6.68 \\
\hline 2 & S-2 & F & 7.00 & 6.78 \\
\hline 3 & S-3 & F & 6.90 & 6.67 \\
\hline 4 & S-4 & F & 7.15 & 6.78 \\
\hline 5 & S-5 & F & 7.00 & 6.85 \\
\hline 6 & S-6 & F & 7.25 & 7.00 \\
\hline 7 & S-7 & F & 6.87 & 6.65 \\
\hline 8 & S-8 & F & 7.25 & 6.98 \\
\hline 9 & S-9 & F & 6.90 & 6.63 \\
\hline 10 & S-10 & F & 6.90 & 6.72 \\
\hline 11 & S-11 & F & 7.15 & 6.97 \\
\hline 12 & S-12 & F & 7.21 & 7.00 \\
\hline 13 & S-13 & F & 7.20 & 6.90 \\
\hline 14 & S-14 & F & 6.90 & 6.62 \\
\hline 15 & S-15 & F & 7.32 & 7.20 \\
\hline 16 & S-16 & F & 7.27 & 7.03 \\
\hline 17 & S-17 & F & 7.10 & 6.68 \\
\hline 18 & S-18 & F & 7.27 & 7.14 \\
\hline 19 & S-19 & M & 6.90 & 6.78 \\
\hline 20 & S-20 & & & \\
\hline
\end{tabular}

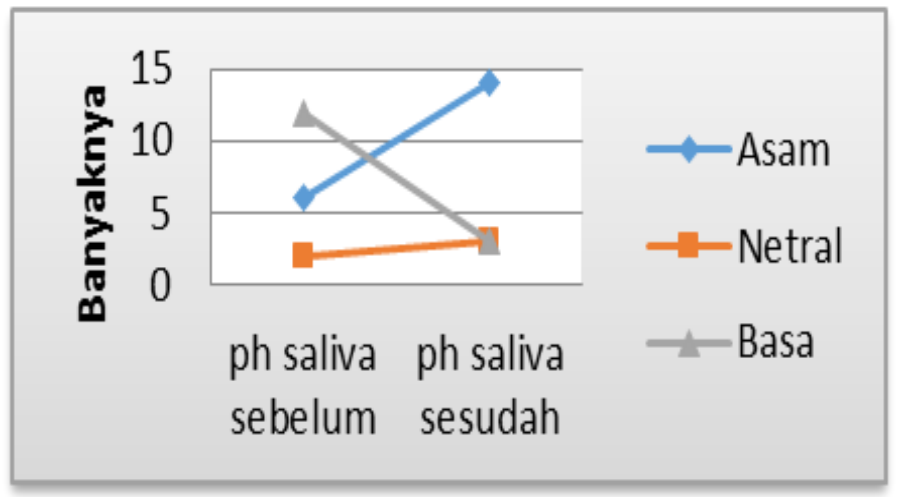

Figure 2. Graph of changes in salivary $\mathrm{pH}$ before and after in the experimental group

Statistical tests have been conducted through paired sample t-test to find out whether there are differences 
before and after the control group and the experimental group. The statistical test results can be seen in the table 3.

\begin{tabular}{|c|c|c|c|c|c|}
\hline \multirow{2}{*}{ Perbandingan $p H$ Saliva } & \multirow{2}{*}{ Mean } & \multirow{2}{*}{$\mathrm{N}$} & \multirow{2}{*}{$\begin{array}{c}\text { Std } \\
\text { Deviation }\end{array}$} & \multicolumn{2}{|c|}{ Uji Statistik } \\
\hline & & & & $\mathrm{T}$ & $\mathrm{P}$ \\
\hline Sebelum Kelompok Kontrol & 6.983 & 20 & 0.18212 & \multirow{2}{*}{0.538} & \multirow{2}{*}{0.597} \\
\hline Sebelum Kelompok Kontrol & 6.98 & 20 & 0.18561 & & \\
\hline Sebelum Kelompok Eksperimen & 7.102 & 20 & 0.1583 & \multirow{2}{*}{12,801} & \multirow[b]{2}{*}{0} \\
\hline Sesudah Kelompok Eksperimen & 6.853 & 20 & 0.17818 & & \\
\hline
\end{tabular}

The results of research conducted at the Dental Nursing Campus of the Poltekkes Kemenkes Tasikmalaya showed that the results of the study based on table 6 show that there were more female sex samples $(34 \%)$ while male samples were $6(15 \%)$. Dissemination of the sample by age is shown in table 7 , the 18 -year-old sample is more than numbered 19 people (47.5\%), the 19 -year-old sample is 8 people ( $45 \%)$, while the 17 -year-old sample is smaller that is amounting to 3 people $(7.5 \%)$. Checking the acidity $(\mathrm{pH})$ of saliva in the control group after 2 times of examination, namely before and after no change, that is the acidic criteria before 10 people $(50 \%)$, after 10 people $(50 \%)$, neutral criteria before 1 person $(5 \%)$ and 1 person $(5 \%)$ when after the examination, the same as the basic criteria before the examination were 9 people (45\%) and when after the examination there were 9 people $(45 \%)$.

In contrast with the control group, salivary $\mathrm{pH}$ results in the experimental group were compared between before and after. The criteria for acid before being treated were 6 people $(30 \%)$ and after being treated to 14 people $(70 \%)$, the neutral criteria before being treated as many as 2 people (10\%) to 3 people (15\%) after being treated, any basic criteria visible comparison before and after being treated from 12 people $(60 \%)$ when after consuming a banana chicken (musa acuminate colla) to 3 people (15\%).

Based on statistical tests using paired sample t-test, it can be seen that the average $\mathrm{pH}$ of saliva before and after the control group did not show a significant difference of 6.983 (acidic criteria) to 6.980 (acidic criteria) with the Pvalue of the $t$ value of 0.597 , which means $p>0.05$ then the initial hypothesis is accepted meaning that the salivary $\mathrm{pH}$ before and after the control group did not occur significant changes in salivary $p H$. Statistical test results in the experimental group to find out whether there were differences in salivary $\mathrm{pH}$ before and after consuming chicken bananas (musa acuminata colla) and the results were fairly significant changes, namely 7.102 (baseline criteria) to 6.853 (acidic criteria), seen from the P-value tvalue of the t-test was $p=0.00$, so the initial hypothesis was rejected meaning that there was a difference in salivary $\mathrm{pH}$ before and after consuming the banana chicken (musa acuminata colla) in the first semester of Diploma students of the Dental Nursing Department of Poltekkes Kemenkes Tasikmalaya.

Chicken banana (musa acuminata colla) is a plant that is rich in carbohydrates which is quite high and can be used as an energy producer. Carbohydrate-rich foods can reduce the $\mathrm{pH}$ of saliva because it can increase the metabolism of acid production by bacteria, the optimum degree of acidity $(\mathrm{pH})$ of saliva against the growth of bacteria such as streptococcus mutans and lactobacillus between 4.5-5.5 so that it can increase the risk of caries. Fermented carbohydrates can reduce the $\mathrm{pH}$ of saliva will cause hydrogen ions to increase so that it can damage the hydroxyapatite bonds in the teeth and will dissolve enamel crystals.

Research conducted by Afrina, Amirza \& Chrismirina (2014) regarding changes in salivary $\mathrm{pH}$ before and after consuming chicken bananas (musa acuminata colla) in FKG UNSYIAH class of 2014 students revealed changes in salivary $\mathrm{pH}$ after consuming chicken bananas (musa acuminata colla) with an average decrease in salivary $\mathrm{pH}$ of 0.29 and tends to be acidic. The results of the study have been carried out in line with the study because in the paired-sample t-test the results of the research in the experimental group showed significant differences before and after consuming the banana chicken (musa acuminata colla). The decrease in average salivary $\mathrm{pH}$ in the experimental group was 0.249 with a Pvalue of 0.00 , this is due to the fermented carbohydrate content in chicken bananas (musa acuminata colla).

The salivary rate can adjust the salivary buffer balance, it is an acid neutralization system that is quite effective. A good flow of saliva is debris and microorganism cleaning factor on the tooth surface, besides that saliva also has a natural source of protection so that it can repair tooth tissue due to damage caused by acid [3].

\section{CONCLUSION}

Results of research on Comparison of Salivary $\mathrm{pH}$ Before and After Consuming Chicken Banana (musa acuminata colla) in First semester of Diploma Students of the Dental Nursing Department of Poltekkes Kemenkes Tasikmalaya, obtained the results of differences in salivary $\mathrm{pH}$ before and after, from saliva $\mathrm{pH} 7,102$ (baseline criteria) after after treated to 6.853 (acid criteria).

\section{REFERENCES}

[1] Afrina, Amirza, N. S., \& Chrismirina, S. (2014). Perubahan pH Saliva Sebelum dan Sesudah Mengonsumsi Buah Pisang Ayam 
(Musa Acuminata Colla) pada Mahasiswa FKG UNSYIAH Angkatan 2014. Cakradonya Dental Journal:10(1), 44-48.

[2] Badan Penelitian dan Pengembangan Kesehatan Kementrian Kesehatan RI. (2018). Riset Kesehatan Dasar 2018. Jakarta: Badan Penelitian dan Pengembangan Kesehatan Kementrian Kesehatan RI.

[3] Bahar, A. (2011). Paradigma Baru Pencegahan Karies Gigi. Jakarta: Lembaga Penerbit Fakultas Ekonomi Universtas Indonesia

[4] Jovina, T. A., N, I. T., \& Surarti, M. A. (2017). Pengaruh (pH) Saliva Terhadap Terjadinya Karies Gigi Pada Anak Usia Prasekolah. Buletin Penelitian Kesehatan Vol 45 No 4, 241-248.

[5] Jyothirmayi, N., \& Rao, N. (2015). Banana Medicinal Uses. Journal of Medical Science \& Technologi , 152-160.

[6] Kasuma, N. (2015). Fisiologi dan Patologi Saliva. Padang: Andalas University Press

[7] Notoadmodjo, S. (2010). Metodologi Penelitian Kesehatan. Jakarta: Rineka Cipta.
[8] Nugroho, C. (2016). Pengaruh Mengkonsumsi Buah Nanas Terhadap pH Saliva Pada Satriwati Usia 12-16 Tahun Pesantren Perguruan Sukahideng Kabupaten Tasikmalaya. Journal ARSA, 10-15.

[9] Pringadi, J. (2016, Agustus 3). Perbandingan Efektifitas Berkumur Larutan Teh Hijau Dengan Larutan Buah Nanas Dalam Meningkatkan $\mathrm{pH}$ Saliva Pada Mahasiswa Jurusan Keperawatan Gigi Poltekkes Kemenkes Tasikmalaya 2016. Retrieved Desember 15, 2018, from www.issuu.com: http://issuu.co,/jupripringadi/docs/abstrak nanas.docx

[10] Ramayanti, S., \& Purnakarya, I. (2013). Peran Makanan Terhadap Kejadian Karies Gigi. Jurnal Keseatan Masyarakat, 88-93.

[11] Sarwono, S. W. (2013). Psikologi Remaja. Depok: PT RAJA GRAFINDO PERSADA.

[12] Tarigan, R. (2014), Karies Gigi, CV. EGC, Jakarta. 